\title{
MIR194-1 Gene
}

National Cancer Institute

\section{Source}

National Cancer Institute. MIR194-1 Gene. NCI Thesaurus. Code C95034.

This gene may be involved in the modulation of gene expression. 